\title{
Albumin Infusion is not Beneficial in Hypoalbuminemic End-Stage Cancer Patients: A Matched-Pair Analysis
}

\author{
Abdullah BUYUKCELIK ${ }^{1}$, Ahmet DEMIRKAZIK², Bulent YALCIN³, Mutlu DOGAN², \\ Halil KAVGACI ${ }^{4}$, Sahin COBAN ${ }^{5}$, Fikri ICLI ${ }^{2}$ \\ ${ }^{1}$ Acibadem University Faculty of Medicine, Department of Internal Medicine, Istanbul, TURKEY \\ ${ }^{2}$ Ankara University Faculty of Medicine, Department of Medical Oncology, Ankara, TURKEY \\ ${ }^{3}$ Yildirim Beyazit University Faculty of Medicine, Department of Internal Medicine, Ankara, TURKEY \\ ${ }^{4}$ Karadeniz Technical University Faculty of Medicine, Department of Medical Oncology, Trabzon, TURKEY \\ ${ }^{5}$ Diskapi Yildirim Beyazit Training and Research Hospital, Department of Gastroenterology, Ankara, TURKEY
}

\begin{abstract}
In this retrospective study, it was aimed whether albumin infusion is benefical or not in terminally ill hospitalized hypoalbuminemic cancer patients. Between March 2000 and 31 March 2003, the medical records of 27 terminally ill hypoalbuminemic cancer patients who had albumin infusion(Albumin receiving group-ARG), were retrospectively analysed. This grup was matched (1:1) with 27 terminally ill cancer patients who had no albumin infusion (Albumin not receiving group-ANRG), according to age, sex, ECOG PS, diagnosis and the number of metastatic sites. ARG was compared with ANRG, in regard to the changes of pulse rate, blood pressure, in the levels of serum BUN, creatinin, sodium, total protein, and albumin before albumin infusion and 48 hours after albumin infusion, and documented and/or clinical infections after albumin infusion, hospitalization duration, the rate of exitus in hospital and overall survival. There was no difference in patient characteristics between two groups. Likewise, the groups were not different from each other in terms of the changes of puls rate, blood pressure, in the levels of serum BUN, creatinin, sodium, and documented and/or clinical infections after albumin infusion ( $p>0.05$ ). There was a significant increase in the levels of serum total protein and albumin in ARG $(p<0.05)$. The rate of exitus in hospital is not different between two groups. The median duration of hospitalization was longer in ANRG $(p=0.022)$. The overall survival was significantly better in ANRG $(p=0.018)$. Albumin infusion is not benefical in terminally ill hypoalbuminemic cancer patients. Furthermore, it was found that the survival was significantly worse in patients receiving albumin.
\end{abstract}

Keywords: Cancer, Hypoalbuminemia, Terminally ill cancer patient, Albumin infusion

ÖZET

Terminal Dönem Hipoalbuminemik Kanser Hastalarında Albumin İnfüzyonu Yararlı Değildir: Eşleştirilmiş Bir Analiz

Bu çalışmada, hastaneye yatan terminal dönem hipoalbuminemik kanserli hastalarda albumin infüzyonunun fayda sağlayıp sağlayamadığının araştıııması amaçlanmıştır. Bir Mart 2000 ile 31 Mart 2003 tarihleri arasında albumin desteği alan, 27 terminal dönem kanserli hastanın tıbbi kayıtları geriye dönük olarak değerlendirildi. Bu albumin alan grup (ALG), yaş, ECOG PS, cinsiyet, hastalık tanısı ve metastatik bölge sayısına göre, aynı dönemde albumin infüzyonu almayan (ALNG) 27 hipoalbuminemik terminal dönem kanserli hasta ile eşleştirilerek (1:1) kontrol grubu oluşturuldu. 
Albumin infüzyonu öncesi ve infüzyonunun tamamlanmasından 48 saat sonra, nabız sayısı, kan basıncı, BUN, kreatinin, serum sodyum değeri, serum total protein düzeyi, serum albumin düzeyindeki değişiklikler ve albumin infüzyonu sonrası kanıtlanmış ve/veya klinik enfeksiyonlar, böbrek fonsiyonunda bozulma ile hastaların hastanede kalış süreleri, hastanede ölüm oranları ve genel sağkalımları karşılaştııılı. Albumin infüzyonu sonrası, gruplar arasında nabız sayısı, kan basıncı, BUN, kreatinin, serum sodyum değeri değişiklikleri, kanıtlanmış ve/veya klinik enfeksiyon açısından fark yoktu (p> 0.05). Beklenildiği üzere, tedavi sonrası serum total protein ve albumin düzeylerinde, ALG'ta anlamlı artış olmuştur ( $p<0.05)$. İki grupta hastanede eks oranı açısından fark yoktu. ALNG'un medyan hastanede kalış süresi daha uzun bulundu ( $p=0.022)$. Genel sağkalımın, ALNG'ta anlamlı olarak daha iyi olduğu saptandı $(p=0.018)$. Terminal dönem kanserli hipoalbuminemik hastalarda albumin desteği yarar sağlamıyor gibi görünmektedir. Dahası, albumin infüzyonu alan hastalarda sağkalım anlamlı olarak daha kısa bulunmuştur.

Anahtar Kelimeler: Kanser, Hipoalmuminemi, Terminal dönem kanser, Albumin infüzyonu

\section{INTRODUCTION}

Albumin is a medium weight colloid which plays an essential role generating the colloid osmatic pressure. It facilitates fluid retantion in the intravascular space. Apart from its role as a protein maintaining oncotic pressure, albumin binds to a number of ligands and exerts important modulatory functions. Less well appreciated is that albumin can act as an extracellular scavenger in response to oxidative stres. ${ }^{1}$

Hypoalbuminemia is generally interpreted to reflect a state of malnutrition, leading to tissue edema. This has led clinicians to infuse albumin, trying to improve oncotic pressure and relieve tissue edema. Theoretically, hypoalbuminemia can result from decreased synthesis, increased breakdown, increased losses of albumin or dilution of the albumin pool by an increased distribution space, with the exception of congenital analbuminemia. ${ }^{2}$

In cohort studies, investigators found an inverse association between serum albumin level and survival in newly hospitalized patients with acute and chronic disease. ${ }^{3}$ The elevated risk was consistent for cardiovascular, cerebrovascular disease, and cancer. In the British United Provident Association Study, a prospective observational study of 21.520 men, the serum albumin of men who died during 10 years of followup was compared with matched controls. ${ }^{4}$ Although they found no long-term association of low albumin with ischemic heart disease or other circulatory diseases, they did find an inverse association with cancer. The elevated risk for disease was confined to the first few years of follow-up, which implies the decline in albumin levels could be ascribed to the disease process of preclinical cancer. ${ }^{4}$ Althouhg the serum albumin concentration in critically ill patients seems to be inversly related to mortality, there is no evidence that albumin administration reduces mortality in critically ill patients with hypovolemia, burns, or hypoalbuminemia, and a strong suggestion that it may increase mortality. ${ }^{5}$

In the oncology literature, there are many examples of an inverse relationship between serum albumin level and survival with cancer. ${ }^{6}$ In patients with advanced or terminal cancer, it was found that low baseline serum albumin level predicted shorter than expected patient survival. Goransson et al found that low albumin levels (albumin $<3.7 \mathrm{~g} / \mathrm{dL}$ ) were found more often in patients with inoperable cancer than with patients having operable cancers. ${ }^{7}$ In a large investigation that compared various anthropometrical (body mass index) and biochemical variables of nutritional status among 530 cancer patients (87 with hematologic malignancies and the rest with various solid tumors and controls), researchers reported that serum albumin level and body mass index were significantly lower in cancer than in non-cancer subjects. Indeed, many researchers have observed that low level of serum albumin was an independent marker for poorer than expected survival in a variety of neoplastic diseases. ${ }^{6,8-16}$ On the other hand, high level of albumin was found to inhibit the cell proliferation of estrogen responsive breast cancer cells. ${ }^{17}$

Soreide et al reported correlations between serum albumin level and relapse-free survival in stages I and II breast cancer patients. ${ }^{18}$ Heys et al reported that in patients with locally advanced breast cancer undergoing 6 cycles of neoadjuvant chemotherapy, serum albumin level, progressive lymph node involvement with tumor, and advancing tumor stage were independent prognostic indicators for poorer survival. ${ }^{13}$ Pedersen and Sorensen reported that $20.5 \%$ of patients with newly diagnosed early breast cancer and $54.5 \%$ of patients with metastatic disease had increased rates of urinary albumin excretion. ${ }^{19}$ 
Hypoalbuminemia is one of frequently observed laboratory findings in cancer patients. The relatives of cancer patient insist on replacing albumin, and the doctors who care of cancer patients tend to infuse albumin to correct the hypoalbuminemia, although the benefit of albumin infusion in this group of patients is not known. In this retrospective, matched-pair analysis, we aimed to investigate whether albumin infusion in hypoalbuminemic end-stage cancer patients is benefical or not.

\section{PATIENTS AND METHODS}

Definitions of albumin receiving group (ARG) and albumin not receiving group (ANRG) and terminal illness

During 1 March 2000 to 31 Marc 2003, medical records of consecutive 27 terminally ill cancer patients (ARG) who received albumin infusion at the Department of Medical Oncology, Ankara University School of Medicine, Ibni Sina Hospital were reviewed retrospectively. The ARG were matched (1:1) with 27 hipoalbuminemic terminally ill cancer patients (ANRG) who had no albumin infusion, in regard to Eastern Cooperative Oncology Group (ECOG) Performance Status (PS), sex, age ( \pm 5 years), diagnosis of cancer, number of metastatic sites, and the status of liver metastasis. Patients with known cirrhosis or other methabolic liver disease, nephrotic syndrome and protein losing enteropathy were excluded from the study. The patients who had no curative or paliative chemotherapy, radiotherapy or surgical options for treatment, and life expectancy $\leq 3$ months, were defined as end-stage (terminally ill) illness.

Definition of hypoalbuminemia, indication for albumin infusion and evaluated parameters

Serum albumin, total protein, sodium, Blood Urea Nitrogen (BUN), creatinin were measured by autoanalyzer. The levels of serum albumin and total protein were expressed as $\mathrm{g} / \mathrm{dL}$, sodium as $\mathrm{mEq} / \mathrm{L}$, while BUN and creatinin were expressed as $\mathrm{mg} / \mathrm{dL}$. Renal dyfunction after albumin infusion was defined when serum creatinin level inreased more than $1.5 x$ normal upper range of laboratory.

Serum albumin level $<2.5 \mathrm{~g} / \mathrm{dL}$ was considered as hypoalbuminemia and indicated for albumin infusion. Albumin infusion $20 \mathrm{mg}$ per day was continued until serum albumin level was $\geq 2.5 \mathrm{~g} / \mathrm{dL}$. Albumin infusion was not repeated. ARG was compared with ANRG, in regard of the changes in pulse rate, diastolic and systolic blood pressure, ECOG-PS, the levels of serum sodium, BUN, creatinin, total protein and albumin, before and 48 hours after albumin infusion. The groups were also compared for renal dysfunction, the rate of clinical and/or documented and gram negative infections, exitus in hospital, the duration of hospitalization and survival.

\section{Statistical analysis}

All data are expressed as mean and \pm sd unless otherwise indicated. Categorical variables were assessed using chi-square test. Normally distributed data (tested by Kolmogorov-Smirnov test) were analyzed using independent samples t-test. If data was not normally distributed, Mann Whitney U test was used. Survival time was analyzed by the Kaplan-Meier Method using log-rank test. Data were expressed as median (range). A SPSS/PC software package was used for statistical analyses (V 10 SPSS, Chicago, IL). A P value $<0.05$ was considered significant.

\section{RESULTS}

The ARG consisted of 27 consecutive end-stage cancer patients who had albumin infusion, and the ANRG had 27 end-stage cancer patients with no albumin infusion. The baseline characteristics of patients are shown in Table 1. There was no difference in the baseline patient characteristics between two groups. Also, there is no difference in the number of metastatic sites, ratio of liver metastasis, the level of serum total protein, albumin, sodium, BUN and creatinin at the beginning between the groups (Table 1)

\section{Effect of albumin infusion on serum proteins}

Albumin infusion significantly increased levels of serum albumin and total protein in ARG (Table 2). The increment in the level of total protein in ARG was $0.73 \pm 0.46 \mathrm{~g} / \mathrm{dL}$, while it was $0.12 \pm 0.30 \mathrm{~g} / \mathrm{dL}$ in ANRG $(\mathrm{p}=0.027)$. Also, the albumin level was increased by $0.63 \pm 0.48 \mathrm{~g} / \mathrm{dL}$ in $\mathrm{ARG}$ and $0.069 \pm 0.021$ $\mathrm{g} / \mathrm{dL}$ in ANRG $(\mathrm{p}<0.001)$. 


\begin{tabular}{|c|c|c|c|}
\hline Variables & $\begin{array}{l}\text { ARG* } \\
n=27\end{array}$ & $\begin{array}{l}\text { ANRG** } \\
n=27\end{array}$ & $p$ value \\
\hline \multicolumn{4}{|l|}{ Diagnoses } \\
\hline Gastric cancer & 4 & 4 & \\
\hline Lung cancer & 5 & 5 & \\
\hline Pancreatic cancer & 1 & 1 & \\
\hline Breast cancer & 6 & 6 & \\
\hline Colorectal cancer & 2 & 2 & \\
\hline Non-Hodgkin's lymphomas & 5 & 5 & \\
\hline Malignant mesencyhmal tumors & 2 & 2 & \\
\hline Hodgkin's lymphomas & 1 & 1 & \\
\hline Malignant melanoma & 1 & 1 & \\
\hline Age, mean $\pm S D$ & $52.44 \pm 15.33$ & $52.13 \pm 13.35$ & 0.4 \\
\hline Sex, female/male & $11 / 16$ & $11 / 16$ & 0.68 \\
\hline ECOG PS, median (range) & $4(2-4)$ & $3(2-4)$ & 0.75 \\
\hline Number of metastatic sites, median & $2(1-3)$ & $2(1-3)$ & 0.43 \\
\hline Liver metastasis, \% & 50 & 54 & 0.33 \\
\hline Total protein level, $\mathrm{g} / \mathrm{dL}$, mean $\pm \mathrm{SD}$ & $6.03 \pm 0.63$ & $6.35 \pm 0.32$ & 0.48 \\
\hline Albumin level, $g / d L$, mean $\pm S D$ & $2.03 \pm 0.5$ & $2.30 \pm 0.25$ & 0.11 \\
\hline Sodium level, mEq/L, mean $\pm S D$ & $132.4 \pm 6.68$ & $133 \pm 5.21$ & 0.46 \\
\hline $\mathrm{BUN}, \mathrm{mg} / \mathrm{dL}$, mean $\pm \mathrm{SD}$ & $17.81 \pm 7.47$ & $18 \pm 8.11$ & 0.27 \\
\hline Creatinin, mg/dL, mean $\pm \mathrm{SD}$ & $1.11 \pm 0.42$ & $1.08 \pm 0.36$ & 0.48 \\
\hline
\end{tabular}

\section{Changes of baseline characteristic, infections and renal dysfunction after albumin infusion}

Although albumin infusion significantly increased the serum level of albumin and total protein, it was found that it did not affect ECOG PS of patients. Likewise, the number of clinical and/or documented and gram negative infections were not different in ARG than ANRG ( $>>0.05$ ). In the study group, 6 (22.2\%) clinical infections were observed, while 4 (14.81\%) clinical infections were observed in ANRG $(\mathrm{p}=0.62)$. Of those clinical infections in ARG and ANRG, 5 (18.5\%) and 4 (14.81\%) were documented with culture, respectively $(\mathrm{p}=0.35)$. Four $(14.8 \%)$ of documented infections by culture in ARG and 3 $(11.11 \%)$ in ANRG were gram negative $(\mathrm{p}=0.70)$. During follow-up, it was found that renal disfunction devoloped in $3(7.4 \%)$ patients of the study group and $5(18.5 \%)$ and ANRG $(\mathrm{p}=0.49)$.

\section{Effect of albumin on hospital stays, exitus in hospital and survival}

The most important finding of this study was that the albumin replacement did not alter the duration of hospitalization, the ratio of exitus in hospital and survival (Table 2). Furthermore, the survival was worse in the study group. More patients in the study group (55.5\%) died in hospital than in ANRG (38.3\%) (p= 0.052 ), even though the duration of hospitalization was significantly longer in ANRG than the study group ( $\mathrm{p}=0.022$ ). The median survival was 16 days (95\% CI, 3-150 days) in ARG, and 25 days (95\% CI, 7-93 days) in the control group $(\mathrm{p}=0.018)$. 
Table 2. Effects of albumin infusion on end-stage hipoalbuminemic cancer patients.

\begin{tabular}{|c|c|c|c|}
\hline Variables & $\begin{array}{l}\text { ARG* }^{*} \\
\mathrm{n}=27\end{array}$ & $\begin{array}{l}\text { ANRG }^{* *} \\
n=27\end{array}$ & $\mathrm{p}$ value \\
\hline ECOG PS, median (range) & $4(2-4)$ & $4(2-4)$ & 0.72 \\
\hline \multicolumn{4}{|l|}{ Change in level of serum total protein, } \\
\hline mean $\pm S D, g / d L$ & $0.73 \pm 0.46$ & $0.12 \pm 0.30$ & 0.027 \\
\hline \multicolumn{4}{|l|}{ Change in level of serum albumin, } \\
\hline mean $\pm S D, g / d L$ & $0.63 \pm 0.48$ & $0.069 \pm 0.021$ & $<0.001$ \\
\hline Clinical infections, n (\%) & $6(22.2)$ & $4(14.81)$ & 0.62 \\
\hline Documented infections by culture, n(\%) & 5 (18.5) & $4(14.81)$ & 0.35 \\
\hline Gram negative infections, $\mathrm{n}(\%)$ & $4(14.8)$ & $3(11.11)$ & 0.70 \\
\hline Renal dyfunction, n (\%) & $2(7.4)$ & $5(18.5)$ & 0.49 \\
\hline The ratio of exitus in hospital, $\mathrm{n}(\%)$ & $15(55.5)$ & $9(33.3)$ & 0.052 \\
\hline Duration of hospitalization, days, median $(95 \% \mathrm{Cl})$ & $8(3-45)$ & $11(7-32)$ & 0.022 \\
\hline Overal survival, days, median (95\% Cl) & $16(3-150)$ & $25(7-93)$ & 0.018 \\
\hline \multicolumn{4}{|l|}{$\mathrm{Cl}=$ Confidence Interval } \\
\hline *ARG: Albumin receiving group, ${ }^{* \star}$ ANRG: Albun & g group. & & \\
\hline
\end{tabular}

\section{DISCUSSION}

In this retrospective, matched-pair analysis, we investigated the benefit of albumin infusion in hipoalbuminemic end-stage cancer patients. The effects of albumin infusion on ECOG PS, blood pressure, puls rate, serum levels of total protein, albumin, sodium, and renal function, developped infections after albumin infusion, hospital stays and survival were evaluated. In this analysis, albumin infusion did not alter patients' ECOG PS, blood pressure, pulse rate, serum level of sodium. Likewise, the rates of developped infections, renal dysfunction after albumin infusion were not different in ARG than ANRG. However, albumin infusion significantly inreased levels of serum albumin and total protein in ARG. Although the hospital stays were significantly longer in ANRG compared with ARG, the rate of exitus in hospital was higher in ARG. Furthermore, the albumin infusion had a detrimental effect on survival in this study.

The limitations of our study are its retrospective nature and sample size, but we think it is still informative. Although there are many attractive theoretical reasons why maintenance of serum albumin concentrations may be of benefit, there is little or no clinical evidence to support the practice of albumin supplementation. There are no clear indications for albumin administration; rather a feeling that a "natural" protein with a wide range of functions may be maintained within the normal range despite the clear evidence from congenital analbuminemia that it is far from essential. ${ }^{20}$ Studies performed in critically ill patients have not supported the utility of albumin replacement to improve outcome. ${ }^{21}$ A prospective randomized study of albumin versus gelatin solutions for routine fluid replacement in 475 intensive care unit patients did not show any significant differences between duration of stay, complications or outcomes in the two groups.$^{22}$ Unfortunately, albumin treatment appears to increase the relative risk for death in trauma, surgery or burns patients with hypoalbuminemia. ${ }^{23}$ In our study, we found that the albumin infusion was associated with shorter survival.

There has long been a tendency to give intravenous albumin infusion in patients with cirrhotic liver disease while perfoming paracentesis. Nonetheless, studies have not shown that this practice has benefit over infusion of synthetic colloids. ${ }^{24}$ When spontanous bacterial peritonitis develop in patients with cirr- 
hosis, renal function frequently becomes impaired. This impairment is probably related to a reduction in effective arterial blood volume and is associated with a high mortality. In this situation, albumin infusion plus antibiotic compared with antibiotic alone improves renal impairement and reduces mortality, but whether this effect is specific for albumin is unclear. ${ }^{25}$ Ascites in patients with cancer, especially those with peritoneal carcinomatosis, frequently develop and paracentesis to relief symptoms is oftenly employed. There has been no study to assess the albumin infusion in this group of patients so far. In our study, it was not showed that albumin infusion improved renal function or development of infections in hipoalbuminemic cancer patients.

Studies have shown that low levels of serum albumin may be ralated to metabolic changes caused by various factors such as stress, illness, hepatic insufficiency, and depletion of visceral protein mass or synthesizing ability. ${ }^{26-29}$ Very low levels are associated with pronounced malnutrition, and therefore must be considered in determining nutritional adequacy and a need nutrition support. However, the benefit of total parenteral nutrition by adding albumin in the critically ill patients is not clear. Some studies showed a benefit of this practice, but others did not. ${ }^{21,30-33}$ It is obvius that serum albumin levels were elevated in all of these studies.

The use of albumin is expensive for developing or underdevelopped country. Therefore, other treatment options such as nutritional support, effective diuretic for edema or ascites must be considered.

In conclusion, albumin administration to terminally ill cancer patients with hypoalbuminemia is not benefical, and it significantly shortens survival.

\section{REFERENCES}

1. Doweiko JP, Nompleggi DJ. Role of albumin in human physiology and pathophysiology. JPEN 15: 207-211, 1991.

2. Soeters PB. Rationale for albumin infusions. Current Opinion in Clinical Nutrition and Metabolic Care 12: 258264, 2009.

3. D’Erasmo E, Pisani D, Ragno A, et al. Serum albumin level at admission: Mortality and clinical outcome in geriatric patients. Am J Med Sci 314: 17-20, 1997.
4. Law MR, Morris JK, Wald NJ, Hale AK. Serum albumin and mortality in the BUPA study. British United Provident Association. Int J Epidemiol 23: 38-41,1994.

5. Cochrane Injuries Group Albumin Reviewers. Human albumin administration in critically ill patients: systematic review of randomised controlled trials. BMJ 317: 235240, 1998.

6. Vigano A, Bruera E, Jhangri GS, et al. Clinical survival predictors in patients with advanced cancer. Arch Intern Med 160: 861-868, 2000.

7. Goransson J, Jonsson S, Lasson A. Pre-operative plasma levels of C-reactive protein, albumin and various plasma protease inhibitors for the pre-operative assessment of operability and recurrence in cancer surgery. Eur J Surg Oncol 22: 607-617, 1996.

8. Fiorenza AM, Branchi A, Sommariva D. Serum lipoprotein profile in patients with cancer: A comparison with noncancer subjects. Int J Clin Lab Res 30: 141-145, 2000.

9. Schwarzbaum JL, Lal P, Evanoff W, et al. Presurgical serum albumin levels predict survival time from glioblastoma multiforme. J Neurooncol 43: 35-41, 1999.

10. Maestu I, Pastor M, Gomez-Codina J, et al. Pretreatment prognostic factors for survival in small-cell lung cancer: $A$ new prognostic index and validation of three known prognostic indices on 341 patients. Ann Oncol 8: 547553, 1997.

11. Maeda T, Ueoka H, Tabata M, et al. Prognostic factors in advanced non-small cell lung cancer: Elevated serum levels of neuron specific enolase indicate poor prognosis. Jpn J Clin Oncol 30: 534-541, 2000.

12. Tas F, Aykan NF, Aydiner A, et al. The roles of chemotherapy and surgery in gastric carcinoma and the influence of prognostic factors on survival. Am J Clin Oncol 23: 53-57, 2000

13. Heys SD, Ogston KN, Simpson WG, et al. Acute phase proteins in patients with large and locally advanced breast cancer treated with neo-adjuvant chemotherapy: Response and survival. Int J Oncol 13: 589-594, 1998.

14. Masutani M, Akusawa H, Kadota A, et al. A phase III randomized trial of cisplatin plus vindesine versus cisplatin plus vindesine plus mitomycin $\mathrm{C}$ versus cisplatin plus vindesine plus ifosfamide for advanced non-small-cell lung cancer. Respirology 1: 49-54, 1996.

15. Janisch L, Mick R, Schilsky RL, et al. Prognostic factors for survival in patients treated in phase I clinical trials. Cancer 74: 1965-1973, 1994.

16. Hasenclever D, Diehl V. A prognostic score for advanced Hodgkin's disease: International Prognostic Factors Project on advanced Hodgkin Disease. N Engl J Med 339: 1506-1514, 1998.

17. Laursen I, Briand P, Lykkesfeldt AE. Serum albumin as a modulator on growth of the human breast cancer cell line, MCF-7. Anticancer Res 10: 343-351, 1990.

18. Soreide JA, Lea OA, Kvinnsland S. Cytosol albumin content in operable breast cancer. Correlations to steroid hormone receptors, other prognostic factors and prognosis. Acta Oncol 30: 797-802, 1991.

19. Pedersen LM, Sorensen PG. Increased urinary albumin excretion rate in breast cancer patients. Acta Oncol 39: 145-149, 2000. 
20. Watkins S, Madison J, Galliano M, et al. Analbuminemia: three cases resulting from different point mutations in the albumin gene. Proc Nat Acad Sci USA 91: 9417-9421, 1994.

21. Golub R, Sorrento JJ Jr, Cantu R Jr, et al. Efficacy of albumin supplementation in the surgical intensive care unit: A prospective, randomized study. Crit Care Med 22: 613-619, 1994.

22. Stockwell MA, Soni N, Riley B. Colloid solutions in the critically ill. Anaesthesia 47: 3-6, 1992.

23. Cook D, Guyatt G. Colloid use for fluid resuscitation: evidence and spin. Ann Intern Med 135: 205-208, 2001.

24. Salerno F, Badalamenti S, Lorenzano E, et al. Randomized comparative study of hemaccel vs. albumin infusion after total paracentesis in cirrhotic patients with refractory ascites. Hepatology 13: 707-713, 1991.

25. Sort P, Navasa M, Arroyo V, et al. Effect of intravenous albumin on renal impairment and mortality in patients with cirrhosis and spontaneous bacterial peritonitis. N Engl J Med 341: 403-409, 1999.

26. Brennan MF. Uncomplicated starvation versus cancer cachexia. Cancer Res 37: 2359-2365, 1977.

27. Baumgartner RN, Koehler KM, Romero L, et al. Serum albumin is associated with skeletal muscle in elderly men and women. Am J Clin Nutr 64: 552-558, 1996.

28. Anton $\mathrm{AH}$. The relationship between the binding of sulfonamides to albumin and their antibacterial efficacy. J Pharm Exp Ther 129: 282-290, 1960.

29. Robertson AD, Grutsch JF. Biphasic responses, quantal signals and cellular behavior. J Theor Biol 125: 41-60, 1987.

30. Brown RO, Bradley JE, Bekemeyer WB, Luther RW. Effect of albumin supplementation during parenteral nutrition on hospital mortality. Crit Care Med 16: 11771182, 1988.

31. Foley EF, Borlase BC, Dzik WH, et al. Albumin supplementation in the critically ill. Arch Surg 125: 739-742, 1990.
32. Wojtysiak SL, Brown RO, Roberson D, et al. Effect of hypoalbuminaemia and parenteral nutrition on free water excretion and electrolyte free water resorption. Crit Care Med 20: 164-169, 1992.

33. Rubin H, Carlson S, DeMeo M, et al. Randomized, doubleblind study of intravenous human albumin in hypoalbuminemic patients receiving total parenteral nutrition. Crit Care Med 25: 249-252, 1997.

\section{Correspondence}

Dr. Abdullah BÜYÜKÇELIKK

Acıbadem Kayseri Hastanesi

Medikal Onkoloji Bölümü

Seyitgazi Mah. MKP Bulvarı No: 1 1-A

Melikgazi, KAYSERI / TURKEY

$$
\text { Tel: } \quad \text { (+90.352) } 2073846
$$

Fax: (+90.352) 2074378

e-mail: abdullah.buyukcelik@acibadem.edu.tr abdullah.buyukcelik@acibadem.com.tr 